\title{
Investigation of The Relationship Between The Life Quality and Life Satisfactions of Karate Do Coaches in The Covid-19 Outbreak Process
}

\author{
FUAT GÖKDERE ${ }^{1}$, ŞEBNEM ŞARVAN CENGIZ² \\ ${ }^{1}$ Manisa Celal Bayar University Social Sciences Institute \\ ${ }^{2}$ Manisa Celal Bayar University Faculty Of Sports Sciences \\ Correspondence to: şebnem şarvan cengiz, Email: csebnem@gmail.com, Cell: +905326505404
}

\begin{abstract}
Aim: The aim of the study is to report the quality of life and life satisfaction of karate-do trainers during the covid-19 epidemic and public health restrictions, and to examine the relationships between trainers' quality of life and life satisfaction while the restrictions persist.

Methods: During public health restrictions, Karate Do trainers were recruited through an online survey and social media posting of demographics, quality of life, and life satisfaction sections. The World Health Organization Quality of Life Scale (WHOQOLBREF) and the 7-point Likert-type Life Satisfaction Scale developed by Diener et al. (1985) and validated in Turkish by Bekmezci and Mert (2018) were used. IBM SPSS 22 package was used for data analysis. Independent Sample T test, One way Anova Test and Pearson Correlation Test were used with the program. The significance level of all evaluations was taken into account as $\mathrm{p}<0.05$.

Results: In the findings obtained in the study, no significant difference was found between the participants' gender, age, educational status, residence and coaching time, and life satisfaction in the sub-dimensions of quality of life. A significant difference was found between the monthly income levels of the participants and the sub-dimensions of the quality of life, namely the psychological field and the environmental field and life satisfaction. During the pandemic period, significant differences were observed in the levels of paying attention to mask-distance-hygiene rules and in all sub-dimensions of quality of life. As a result of the correlation analysis, it was observed that as the quality of life of karate do trainers increased, life satisfaction at the midlow level increased positively.

Conclusion: No significant difference was found between the variables of gender, age, education level, residence and duration of coaching of karate do trainers and quality of life and life satisfaction. It was observed that there was a significant difference between the monthly income of the trainers and the sub-dimensions of the quality of life, namely psychological domain, environmental domain and life satisfaction. As karate do trainers pay attention to hygiene rules in every period, significant differences were observed between the level of attention to mask-distance-hygiene rules and all sub-dimensions of quality of life during the pandemic period. From this point of view, it can be said that Karate Do trainers pay attention to hygiene rules, especially during the pandemic period. In our study, it was observed that as the quality of life of Karate Do trainers increased, their life satisfaction also increased moderately positively. It is predicted that this ratio will increase even more with the new regulations to be made on the living standards and personal rights of Karate Do trainers.
\end{abstract}

Keywords: Covid-19, Karate Trainers, Quality of Life, Life Satisfaction.

\section{INTRODUCTION}

Karate Do Martial Arts are carried out today both in the form of sportive Karate Do and traditional Karate Do. We will investigate whether the traditional Karate Do, which has been esotericly transmitted for 2000 years, and the sport Karate Do, which will participate in the 2021 Tokyo Olympics as an Olympic branch, have a relationship with the quality of life and life satisfaction.

When Karate Do Martial Arts are considered in terms of word meanings, black; represents the void. The form of all visible reality is emptiness, in short "nothingness". The void is the beginning of all reality. In the void there is the existence of virtue and wisdom. This refers to an individual with empty hands. In this respect, it symbolizes peace and brotherhood. Te; Although its meaning is "hand", it is used in the sense of art and technique. The open hand symbolizes friendship, peace, and absence of ulterior motives in most cultures. It represents an artistic productivity. Do; It is the "Soul Path" that reveals the talents of the individual in various branches of art in Japanese culture. The path of Do is reached with a deepened discipline. The "Road" that is meant to be explained here is a developed mental void with no visible end (Alpay, 2016).

COVID-19 emerged as a result of transmission of the virus from bat to human in a fish market in Wuhan province of China in December 2019 and was named (2019nCoV) (Huang et al., 2020; as cited in Tunç et al., 2020). The coronavirus (CoV), identified on January 13,2020 , is from the family of viruses that cause many diseases such as Mers and Sars. The COVID-19 pandemic, which causes changes in people's living conditions, has had a negative impact on economic, social and commercial aspects in many areas such as health, education, industry, transportation, tourism and sports. Quarantine and sedentary lifestyle have caused negative effects on the quality of life of individuals (Tunç et al., 2020).
During the COVID-19 epidemic that emerged at the beginning of 2020 , individuals had to do social isolation. This resulted in insufficient physical activity. Since individuals cannot exercise, loss of muscle strength and weaknesses in the immune system have begun to be seen more (Kartal, Engin, \& Kanmış, 2020).

We call quality the feature that indicates how a person, object or experience is qualitatively, and that can measure and evaluate its distinctive superiority from other things. In other words, quality is a quality characteristic that determines a person's intellectual and moral nature (Bozkurt, 2003).

Quality of life is about self-development, enrichment of personal life and reaching goals. A quality life is to question oneself, to know oneself, and to make one's life peaceful, balanced and harmonious (Bozkurt, 2003).

In the field of psychology, which is one of the fields that try to determine the common parameters of the quality of life, important information has been obtained by the studies of Abraham Maslow, Carl Rogers and Fritz Perls. As a result of the studies, the following formula was obtained: Quality Life $=$ Health $\times$ Effort. Health in the formula means how well we can be at each of the physical, emotional, social etc. aspects of life. Effort refers to two separate factors. 1. Action; What are you doing to protect and improve your health? 2. Emotion; It means to be more creative and productive, the effort of the person who consists of emotion, happiness, integrity and the pleasure of fulfilling a wish (Karaküçük, 2016:110).

The World Health Organization defines quality of life as individuals' perceptions of their life in their cultural context and their value systems and goals, standards and interests. In WHO's definition of quality of life; There are 6 fields including physical health, psychological state, level of independence, social relations, 
environmental characteristics and spirituality (Perim, 2007).

According to Savcı (2006), situations that reduce the quality of life are; not meeting basic needs, change in body image, inadequacy of self-care behaviors and activities of daily living, chronic fatigue, exhaustion, deterioration in sexual functions, concerns about the future, inadequacies in support systems, acute or chronic health problems. Situations that increase the quality of life are; being in economic and social security, living in safety, having comfort and necessary facilities, having a meaningful and active life, having positive relations with his/her immediate environment, having entertainment and activities that he/she enjoys, being respected, having autonomy, valuing his privacy, expressing himself, being functionally competent, being perceived as a unique individual, being at peace, and respecting his beliefs and values.

Quality of life can be summarized as the individual's way of perceiving his own situation within the culture and value system in which he lives. The concept of quality of life includes the individual's perception of their physical and mental health, as well as their level of independence and social relationships, hopes, interests, and standard of living. (Ekim \& Ocakçı, 2012; as cited in Beğli, 2016).

Among the components of quality of life, there are facts such as education, health, equality, dignity and physical activity. If one of these cases is missing, the quality of life may be affected (Özata, 2019).

The lexical meaning of satisfaction is defined as ensuring the realization of a desired thing, reaching the satisfaction of the heart, content and saturation (TDK dictionary, 2021).

Life satisfaction, which was first put forward by Neugarten in 1961 , has guided many researchers later on. Satisfaction is the fulfillment of expectations, needs, desires and wishes. Life satisfaction is the state or result obtained by comparing a person's expectations (what he wants) with what he has. When life satisfaction is mentioned, it is understood not the satisfaction in a particular situation, but the satisfaction in all experiences in general (Özer \& Karabulut, 2003).

It is stated in the literature that life satisfaction has a significant effect on the quality of life, which includes physiological and psychological well-being. In this regard, studies have been carried out to measure life satisfaction through variables such as health, well-being and satisfaction, and life satisfaction has been shown as an important source of quality of life experience (Gordon \& Caltabiano, 1996:885; as cited in Sevil, 2015).

\section{MATERIAL AND METHODS}

Purpose and Importance of the Research: The aim of the research is to report the quality of life and life satisfaction of Karate-Do trainers during the covid-19 epidemic and public health restrictions, and to examine the relationships between the quality of life and life satisfaction of the trainers during the period of restrictions. When the keywords "Karate trainers, quality of life, life satisfaction" were written in the database of the National Thesis Center between January 8 and February 3, 2021, the dates of the research, it was seen that no thesis was written on the subject. When the articles made in Turkey are examined in terms of keywords, it is seen that there is no article written on this subject. It is thought that the research is important in terms of the quality of life of Karate Do trainers.

Data Collection Method: Data Collection Tools: During public health restrictions, Karate-Do trainers were included in the research through an online survey consisting of demographic information, quality of life and life satisfaction sections and social media announcement. Data collection tools used in the research;

1 "General Information Form": It is the section for demographic information consisting of 7 questions (gender, age, education level, residence, length of coaching, monthly income, compliance with hygiene rules in the dojo) developed by the researchers.

2 "World Health Organization Quality of Life Scale-Short Form (WHOQOL-BREF)": It consists of 27 questions in 5-point Likert type. The $3 \mathrm{rd}, 4$ th, 26 th and 27 th questions in the scale are scored by reverse coding. Question 27 is used for national studies. The 27th question is not included in the scoring, it is evaluated separately (Telatar, 2007). While calculating the quality of life scores, it is calculated by multiplying the arithmetic mean of the participants' scores in the sub-dimension areas by 4 (Gönülateş, 2016).

3 The 7-point Likert-type "Life Satisfaction Scale" developed by Diener and his friends (1985) and validated in Turkish (Bekmezci, 2018) was used. Independent Sample T test, One way Anova test and Pearson Correlation test were used with SPSS 22 package program for data analysis. The significance level of all evaluations was taken into account as $(p<0.05)$.

Between January 8 and February 3, 2021, participants filled out the surveys using online survey software (Google surveys). It was determined that 198 participants completed the online questionnaire, but 2 of the participants were under the age of 18 and were therefore excluded from the dataset.

Population and sample: The research population consists of all Karate Do trainers qualified with at least 1st Level Trainer Certificate by the Turkish Karate Federation. The research sample, on the other hand, consists of a total of 196 trainers, 30 women and 166 men, who have at least 1st Level Coaching Course Certificate who participated in the research voluntarily.

Reliability: It was determined that 198 participants completed the online questionnaire, but 2 of the participants were under the age of 18 and were therefore excluded from the dataset.

Participants were informed that the study was for Karate Do trainers only, and that they should respond to the scale they filled out online, taking into account the last 15 days.

The online survey software (Google surveys) was transferred to the MS Excell environment and every analysis and process was recorded using the IBM SPSS 22 package program.

Child (2006) and Tabachnick and Fidell (2001) argued that a sample size of 5 times the number of items is sufficient. According to Kline (2005), the sample size should be at least 10 times the number of parameters to be estimated by the model in order to perform the analysis. He says that 5 times may be sufficient for data sets where the assumption of normal distribution is provided. Since the ages of 2 participants participating in the study were under the age of 18 , they were not included in the study. A total of 196 Karate Do trainers, 30 women and 166 men, participated in our survey. 27 items WHOQOL-BREF and 5 items Life Satisfaction Scale were used and the total number of items is 32 . Since $32 \times 5=160$, it was seen that the participants were sufficient with the number of 196 participants.

Analysis of Data: IBM SPSS 22 package program was used in the analysis of the data. Standard deviation and percentage values are included in the descriptive statistical representation of the data. The normal distribution of the data was examined by examining Kolmogorov-Smirnov (K-S) test values.

\section{RESULT}

Table 1. Skewness, kurtosis and normality tests of factors.
\begin{tabular}{|l|l|l|l|l|}
\hline & & & & $\begin{array}{l}\text { Kolmogorov } \\
\text { Smirnov (K-S) }\end{array}$ \\
\hline Factors & $\mathrm{n}$ & Skewness & Kurtosis & $\mathrm{p}$ \\
\hline Physical Field & 196 &,- 672 &, 459 & .000 \\
\hline $\begin{array}{l}\text { Psychological } \\
\text { Field }\end{array}$ & 196 &,- 989 & 1,892 & .000 \\
\hline Social Field & 196 &,- 820 & 1,311 & .000 \\
\hline $\begin{array}{l}\text { Environmental } \\
\text { Field }\end{array}$ & 196 &,- 318 &, 118 & .003 \\
\hline Life Satisfaction & 196 & $-1,023$ &, 402 & .000 \\
\hline
\end{tabular}

As a result of the test, it was seen that the values did not show normal distribution ( $p<.05$ ). According to George and Mallery (2010), the ratio of the skewness and kurtosis values of the items in the measurement tool to the standard deviation of $\mp 2.0$ indicates that a normal distribution is achieved. Based on the law of large numbers and the central limit theorem, since the sample 
size was large enough (İnal \& Günay, 1993; Johnson \& Wichern 2002), it was decided to apply parametric statistical tests, assuming that the distribution was normal. In the study, Independent Samples T Test was used to examine the significant difference of two groups from parametric tests, One way Anova analysis to examine the significant difference between three or more groups, and Pearson Correlation analysis to examine the relationship between variables. For statistical analysis of the data, descriptive methods such as frequency (n), percentages (\%), arithmetic means (A. Mean) and standard deviation (S.d.) were used.

Findings Regarding the Demographic Characteristics of the Participants: Frequency and percentage data showing the gender, age, education level, residence area, coaching time, monthly average income level and compliance with mask-distancehygiene rules in Karate Do halls during the epidemic period of the participants in the research are shown in the tables below.

Table 2. Distribution of Participants by Demographic Characteristics

\begin{tabular}{|c|c|c|c|}
\hline Factors & Group & $\mathrm{n}$ & $\%$ \\
\hline & Female & 30 & 15,3 \\
\hline \multirow[t]{5}{*}{ Gender } & Male & 166 & 84,7 \\
\hline & Total & 196 & 100 \\
\hline & $18-25$ & 23 & 11,7 \\
\hline & $26-35$ & 40 & 20,4 \\
\hline & $36-45$ & 63 & 32,1 \\
\hline \multirow[t]{7}{*}{ Age range } & $46-55$ & 55 & 28,1 \\
\hline & $56-65$ & 14 & 7,1 \\
\hline & 66 and over & 1 & 0,5 \\
\hline & Total & 196 & 100 \\
\hline & Primary School & 1 & 0,5 \\
\hline & Secondary School & 8 & 4,1 \\
\hline & High School & 60 & 30,6 \\
\hline \multirow[t]{5}{*}{ Educational Status } & $\begin{array}{l}\text { Undergraduate/Associate } \\
\text { degree }\end{array}$ & 101 & 51,5 \\
\hline & Master's degree & 23 & 11,7 \\
\hline & Doctorate & 3 & 1,5 \\
\hline & Total & 196 & 100 \\
\hline & Provincial center & 136 & 69,4 \\
\hline \multirow[t]{5}{*}{ Settlement } & District center & 59 & 30,1 \\
\hline & Village & 1 & 0,5 \\
\hline & Total & 196 & 100 \\
\hline & $0-10$ years & 103 & 52,6 \\
\hline & $11-20$ years & 47 & 24,0 \\
\hline \multirow[t]{6}{*}{ Coaching Time } & 21-30 years & 27 & 13,8 \\
\hline & $31-40$ years & 18 & 9,2 \\
\hline & 40 years and over & 1 & 0,5 \\
\hline & Total & 196 & 100 \\
\hline & $0-1000$ TRY & 30 & 15,3 \\
\hline & 1001-3000 TRY & 47 & 24,0 \\
\hline \multirow[t]{5}{*}{ Monthly Income } & 3001-5000 TRY & 71 & 36,2 \\
\hline & 5001-10000 TRY & 41 & 20,9 \\
\hline & 10000 TRY and over & 7 & 3,6 \\
\hline & Total & 196 & 100 \\
\hline & Never & 4 & 2,0 \\
\hline \multirow{3}{*}{$\begin{array}{l}\text { Mask- Distance- } \\
\text { Hygiene }\end{array}$} & Rarely & 8 & 4,1 \\
\hline & Always & 184 & 93,9 \\
\hline & Total & 196 & 100 \\
\hline
\end{tabular}

When Table 2 is examined, $15.3 \%$ (30 people) of the participants are women and $84.7 \%$ (166 people) are men. $11.7 \%$ of the participants are between the ages of 18 and 25 (23 people), $20.4 \%$ are between the ages of 26 and 35 (40 people), $32.1 \%$ are between the ages of 36 and 45 (63 people), \% $28.1 \%$ of them are between the ages of 46 and 55 ( 55 people), $7.1 \%$ are between the ages of 56 and 65 (14 people) and $0.5 \%$ are over 66 years old (1 person). $0.5 \%$ ( 1 person) of the participants were primary school graduate, $4.1 \%$ (8 people) secondary school graduate, $30.6 \%(60$ people) high school graduate, $51.5 \%$ (101 people) have associate degree or undergraduate, $11.7 \%$ (23 people) have master's degree, $1.5 \%$ have doctorate (3 people). It is seen that $69.4 \%$ (136 people) of the participants live in the city center, $30.1 \%$ (59 people) live in the district center and $0.5 \%$ ( 1 person) live in the village. When the table is examined, it is seen that $52.6 \%$ (103 people) of the participants are between 0 and 10 years, 24\% ( 47 people) are between 11 and 20 years, 13.8\% (27 people) are between 21 and 30 years, $9.2 \%$ It is seen that 18 people (18 people) have been Karate Do trainers for 31 to 40 years, $0.5 \%$ ( 1 person) for 40 years or more. $15.3 \%$ (30 people) of the participants 0 to $1000 \mathrm{TRY}, 24 \%$ (47 people) 1001 to 3000 TRY, 36.2\% (71 people) 3001 to 5000 TRY, $20.9 \%$ (41 people) have monthly incomes of 5001 to 10000 TRY, $3.6 \%$ of them (7 people) have a monthly income of 10000TRY or more.

\begin{tabular}{|c|c|c|c|c|c|c|c|}
\hline \multicolumn{2}{|c|}{ Gender } & $\mathrm{n}$ & $\begin{array}{l}\text { A. } \\
\text { Mean }\end{array}$ & S.D. & sd. & $\mathrm{t}$ & $p$ \\
\hline \multirow{2}{*}{ Physical Field } & Female & 30 & 3,9190 & ,47851 & \multirow{2}{*}{194} & \multirow{2}{*}{,539 } & \multirow{2}{*}{,591 } \\
\hline & Male & 166 & 3,8580 &, 58586 & & & \\
\hline \multirow{2}{*}{$\begin{array}{l}\text { Psychological } \\
\text { Field }\end{array}$} & Female & 30 & 3,9944 &, 51877 & \multirow{2}{*}{194} & \multirow{2}{*}{1,212} & \multirow{2}{*}{,227 } \\
\hline & Male & 166 & 3,8464 & 63139 & & & \\
\hline \multirow{2}{*}{ Social Field } & Female & 30 & 3,6222 &, 53772 & \multirow{2}{*}{194} & \multirow{2}{*}{,- 150} & \multirow{2}{*}{,881 } \\
\hline & Male & 166 & 3,6426 &, 70550 & & & \\
\hline \multirow{2}{*}{$\begin{array}{l}\text { Environmental } \\
\text { Field }\end{array}$} & Female & 30 & 3,5792 &, 54682 & \multirow{2}{*}{194} & \multirow{2}{*}{,069 } & \multirow{2}{*}{ 945 } \\
\hline & Male & 166 & 3,5715 &, 56245 & & & \\
\hline \multirow{2}{*}{ Life Satisfaction } & Female & 30 & 5,2400 & 1,17374 & \multirow{2}{*}{194} & \multirow{2}{*}{1,415} & \multirow{2}{*}{ 159 } \\
\hline & Male & 166 & 4,8566 & 1,39625 & & & \\
\hline
\end{tabular}

When Table 3 is examined, no significant difference was found between the gender of the participants and the subdimensions of Physical Area, Psychological Area, Social Area, Environmental Area and Life Satisfaction $(P>0.05)$.

One Way Anova Test

Table 4. One-way anova test between age of participants and subdimensions of physical, psychological, social, environmental and life satisfaction.

\begin{tabular}{|c|c|c|c|c|c|c|}
\hline \multicolumn{2}{|l|}{ Factors } & $\begin{array}{l}\text { Sum of } \\
\text { Squares }\end{array}$ & $s d$ & $\begin{array}{l}\text { Mean of } \\
\text { Square }\end{array}$ & $\mathrm{F}$ & $\mathrm{P}$ \\
\hline \multirow[t]{3}{*}{ Physical Field } & \begin{tabular}{|l|} 
Intergroup \\
\end{tabular} & \begin{tabular}{|l|}
, 962 \\
\end{tabular} & 5 & ,192 & \begin{tabular}{|l|}
, 586 \\
\end{tabular} & ,711 \\
\hline & \begin{tabular}{|l|} 
Withingroup \\
\end{tabular} & 62,405 & 190 & ,328 & & \\
\hline & \begin{tabular}{|l|} 
Total \\
\end{tabular} & 63,367 & 195 & & & \\
\hline \multirow{3}{*}{$\begin{array}{l}\text { Psychological } \\
\text { Field }\end{array}$} & \begin{tabular}{|l|} 
Intergroup \\
\end{tabular} & 2,554 & 5 & ,511 & \begin{tabular}{|l}
1,356 \\
\end{tabular} & ,243 \\
\hline & \begin{tabular}{|l|} 
Withingroup \\
\end{tabular} & 71,585 & 190 & ,377 & & \\
\hline & Total & \begin{tabular}{|l|}
74,139 \\
\end{tabular} & 195 & & & \\
\hline \multirow{3}{*}{ Social Field } & \begin{tabular}{|l|} 
Intergroup \\
\end{tabular} & 4,508 & 5 & ,902 & \begin{tabular}{|l|}
1,992 \\
\end{tabular} &, 082 \\
\hline & \begin{tabular}{|l|} 
Withingroup \\
\end{tabular} & 86,013 & 190 & ,453 & & \\
\hline & Total & 90,522 & 195 & & & \\
\hline \multirow{3}{*}{$\begin{array}{l}\text { Environmental } \\
\text { Field }\end{array}$} & \begin{tabular}{|l|} 
Intergroup \\
\end{tabular} & ,440 & 5 & ,088 & \begin{tabular}{|l|}
, 276 \\
\end{tabular} &, 926 \\
\hline & \begin{tabular}{|l|} 
Withingroup \\
\end{tabular} & 60,431 & 190 & ,318 & & \\
\hline & Total & 60,870 & 195 & & & \\
\hline \multirow{3}{*}{$\begin{array}{l}\text { Life } \\
\text { Satisfaction }\end{array}$} & \begin{tabular}{|l|} 
Intergroup \\
\end{tabular} & 20,116 & 5 & 4,023 & 2,214 & ,055 \\
\hline & \begin{tabular}{|l|} 
Withingroup \\
\end{tabular} & 345,239 & 190 & 1,817 & & \\
\hline & Total & 365,354 & 195 & & & \\
\hline
\end{tabular}

hen Table 4 is examined, no significant difference was found between the ages of the participants and the sub-dimensions of physical area, psychological area, social area, environmental area and life satisfaction $(P>0.05)$.

Table 5. One-way anova test between the education levels of the participants and the sub-dimensions of physical, psychological, social, environmental and life satisfaction.

\begin{tabular}{|c|c|c|c|c|c|c|}
\hline \multicolumn{2}{|l|}{ Variants } & \begin{tabular}{|l|} 
Sum of \\
squares
\end{tabular} & sd & $\begin{array}{l}\text { Mean of } \\
\text { squares }\end{array}$ & $\mathrm{F}$ & $\mathrm{P}$ \\
\hline \multirow[t]{3}{*}{ Physical Field } & Intergroup & , 481 & 5 & ,096 & ,291 & ,918 \\
\hline & Withingroup & 62,886 & 190 & ,331 & & \\
\hline & Total & 63,367 & 195 & & & \\
\hline \multirow{3}{*}{$\begin{array}{l}\text { Psychological } \\
\text { Field }\end{array}$} & Intergroup & 1,641 & 5 & ,328 & ,860 &, 509 \\
\hline & Withingroup & 72,498 & 190 & ,382 & & \\
\hline & Total & 74,139 & 195 & & & \\
\hline \multirow[t]{3}{*}{ Social Field } & Intergroup & ,755 & 5 & , 151 & ,320 & ,901 \\
\hline & Withingroup & 89,766 & 190 & ,472 & & \\
\hline & Total & 90,522 & 195 & & & \\
\hline \multirow{3}{*}{$\begin{array}{l}\text { Environmental } \\
\text { Field }\end{array}$} & Intergroup & ,755 & 5 & , 151 & ,478 & ,793 \\
\hline & Withingroup & 60,115 & 190 & ,316 & & \\
\hline & Total & 60,870 & 195 & & & \\
\hline \multirow{3}{*}{$\begin{array}{l}\text { Life } \\
\text { Satisfaction }\end{array}$} & Intergroup & 12,342 & 5 & 2,468 & 1,329 & ,254 \\
\hline & Withingroup & 353,012 & 190 & 1,858 & & \\
\hline & Total & 365,354 & 195 & & & \\
\hline
\end{tabular}


When the values showing the compliance of the participant Karate Do trainers to the mask-distance-hygiene rules in the dojos (karate hall) during the pandemic period are examined, 2\% (4 people) never pay attention to the rules, $4.1 \%$ ( 8 people) rarely pay attention to the rules. and $93.9 \%$ (184 people) seem to always pay attention.

Independent Samples T test

The Independent Samples T Test was conducted to examine whether there was a significant difference between the gender variants of the participants and the sub-dimensions of physical, psychological, social, environmental and life satisfaction. The results are tabulated below.

When Table 5 is examined, no significant difference was found between the educational status of the participants and the sub-dimensions of physical area, psychological area, social area, environmental area and life satisfaction $(P>0.05)$.

Table 6. One-way anova test between the residential units of the participants and the sub-dimensions of physical, psychological, social, environmental and life satisfaction.

\begin{tabular}{|l|l|l|l|l|l|l|}
\hline \multirow{4}{*}{ Variants Variance source } & $\begin{array}{l}\text { Sum of } \\
\text { squares }\end{array}$ & sd & $\begin{array}{l}\text { Mean of } \\
\text { squares }\end{array}$ & $\mathrm{F}$ & $\mathrm{p}$ \\
\hline \multirow{4}{*}{ Physical Field } & Intergroup &, 849 & 2 &, 424 & 1,310 &, 272 \\
\cline { 2 - 8 } & Withingroup & 62,519 & 193 &, 324 & & \\
\cline { 2 - 8 } & Total & 63,367 & 195 & & & \\
\hline \multirow{2}{*}{$\begin{array}{l}\text { Psychological } \\
\text { Field }\end{array}$} & Intergroup &, 017 & 2 &, 009 &, 023 &, 978 \\
\cline { 2 - 8 } & Withingroup & 74,122 & 193 &, 384 & & \\
\cline { 2 - 8 } & Total & 74,139 & 195 & & & \\
\hline \multirow{3}{*}{ Social Field } & Intergroup &, 860 & 2 &, 430 &, 926 &, 398 \\
\cline { 2 - 8 } & Withingroup & 89,661 & 193 &, 465 & & \\
\cline { 2 - 8 } & Total & 90,522 & 195 & & & \\
\hline \multirow{2}{*}{ Environmental } & Intergroup &, 266 & 2 &, 133 &, 424 &, 655 \\
\cline { 2 - 8 } & Withingroup & 60,604 & 193 &, 314 & & \\
\cline { 2 - 8 } & Total & 60,870 & 195 & & & \\
\hline \multirow{2}{*}{$\begin{array}{l}\text { Life } \\
\text { Satisfaction }\end{array}$} & Intergroup &, 792 & 2 &, 396 &, 210 &, 811 \\
\cline { 2 - 8 } & Withingroup & 364,562 & 193 & 1,889 & & \\
\cline { 2 - 8 } & Total & 365,354 & 195 & & & \\
\hline
\end{tabular}

When Table 6 is examined, no significant difference was found between the residential units of the participants and the subdimensions of physical area, psychological area, social area, environmental area and life satisfaction $(P>0.05)$.

Table 7. One-way anova test between participants' coaching time and subdimensions of physical, psychological, social, environmental and life satisfaction.

\begin{tabular}{|c|c|c|c|c|c|c|}
\hline \multicolumn{2}{|l|}{ Variants } & $\begin{array}{l}\text { Sum of } \\
\text { squares }\end{array}$ & sd & $\begin{array}{l}\text { Mean of } \\
\text { squares }\end{array}$ & $\mathrm{F}$ & $\mathrm{P}$ \\
\hline \multirow[t]{3}{*}{ Physical Field } & Intergroup & 1,258 & 4 & ,315 & ,968 & ,427 \\
\hline & Withingroup & 62,109 & 191 & ,325 & & \\
\hline & Total & 63,367 & 195 & & & \\
\hline \multirow{3}{*}{$\begin{array}{l}\text { Psychological } \\
\text { Field }\end{array}$} & Intergroup & 2,683 & 4 & ,671 & 1,793 & ,132 \\
\hline & Withingroup & 71,456 & 191 & ,374 & & \\
\hline & Total & 74,139 & 195 & & & \\
\hline \multirow[t]{3}{*}{ Social Field } & Intergroup & 3,937 & 4 & ,984 & 2,171 & 074 \\
\hline & Withingroup & 86,585 & 191 & 453 & & \\
\hline & Total & 90,522 & 195 & & & \\
\hline \multirow{3}{*}{$\begin{array}{l}\text { Environmental } \\
\text { Field }\end{array}$} & Intergroup &, 474 & 4 & ,118 & ,374 & ,827 \\
\hline & Withingroup & 60,397 & 191 &, 316 & & \\
\hline & Total & 60,870 & 195 & & & \\
\hline \multirow{3}{*}{$\begin{array}{l}\text { Life } \\
\text { Satisfaction }\end{array}$} & Intergroup & 3,671 & 4 & 918 & ,485 & ,747 \\
\hline & Withingroup & 361,683 & 191 & 1,894 & & \\
\hline & Total & 365,354 & 195 & & & \\
\hline
\end{tabular}

When Table 7 is examined, no significant difference was found between the coaching time of the participants and the subdimensions of physical area, psychological area, social area, environmental area and life satisfaction $(P>0.05)$.

When Table 8 is examined, a significant difference was observed between the monthly income levels of the participants and the sub-dimensions of psychological, environmental and life satisfaction $(p<.05)$. There was no significant difference in the physical and social domain sub-dimensions $(P>0.05)$.

When Table 9 is examined, a significant difference was observed in the sub-dimensions of physical area, psychological area, social area and environmental area, with the participant karate do trainers paying attention to mask-distance-hygiene rules in gyms during the pandemic period $(p<.05)$, No significant difference was found with the satisfaction with life sub-dimension $(p>.05)$.

Table 8. One-way anova test between the monthly income levels of the participants and the sub-dimensions of physical, psychological, social, environmental and life satisfaction.

\begin{tabular}{|l|l|l|l|l|l|l|}
\hline \multirow{2}{*}{ Variants } & $\begin{array}{l}\text { Sum of } \\
\text { squares }\end{array}$ & sd & $\begin{array}{l}\text { Mean of } \\
\text { squares }\end{array}$ & $\mathrm{F}$ & $\mathrm{P}$ \\
\hline \multirow{4}{*}{ Physical Field } & Intergroup & 1,564 & 4 &, 391 & 1,208 &, 309 \\
\cline { 2 - 8 } & Withingroup & 61,804 & 191 &, 324 & & \\
\cline { 2 - 8 } & Total & 63,367 & 195 & & & \\
\hline \multirow{3}{*}{$\begin{array}{l}\text { Psychological } \\
\text { Field }\end{array}$} & Intergroup & 4,222 & 4 & 1,056 & 2,884 &, 024 \\
\cline { 2 - 8 } & Withingroup & 69,916 & 191 &, 366 & & \\
\cline { 2 - 8 } & Total & 74,139 & 195 & & & \\
\hline \multirow{4}{*}{ Social Field } & Intergroup & 3,763 & 4 &, 941 & 2,071 &, 086 \\
\cline { 2 - 8 } & Withingroup & 86,758 & 191 &, 454 & & \\
\cline { 2 - 8 } & Total & 90,522 & 195 & & & \\
\hline Field & Intergroup & 7,370 & 4 & 1,842 & 6,578 &, 000 \\
\cline { 2 - 8 } & Withingroup & 53,501 & 191 &, 280 & & \\
\cline { 2 - 8 } & Total & 60,870 & 195 & & & \\
\hline \multirow{2}{*}{$\begin{array}{l}\text { Life } \\
\text { Satisfaction }\end{array}$} & Intergroup & 18,638 & 4 & 4,659 & 2,567 &, 040 \\
\cline { 2 - 8 } & Withingroup & 346,716 & 191 & 1,815 & & \\
\cline { 2 - 8 } & Total & 365,354 & 195 & & & \\
\hline
\end{tabular}

Table 9. One-way anova test between participants' compliance with maskdistance-hygiene rules and sub-dimensions of physical, psychological, social, environmental and life satisfaction.

\begin{tabular}{|c|c|c|c|c|c|c|}
\hline \multicolumn{2}{|c|}{ Variants Variance range } & \multirow{2}{*}{\begin{tabular}{|l|}
$\begin{array}{l}\text { Sum of } \\
\text { squares }\end{array}$ \\
2,146 \\
\end{tabular}} & \multirow{2}{*}{$\begin{array}{l}\text { sd } \\
2\end{array}$} & \multirow{2}{*}{$\begin{array}{l}\begin{array}{l}\text { Mean of } \\
\text { squares }\end{array} \\
1,073\end{array}$} & \multirow{2}{*}{$\begin{array}{l}F \\
3,383\end{array}$} & \multirow{2}{*}{$\begin{array}{l}\mathrm{p} \\
, 036\end{array}$} \\
\hline Physical Field & Intergroup & & & & & \\
\hline & Withingroup & 61,221 & 193 & ,317 & & \\
\hline & Total & 63,367 & 195 & & & \\
\hline \multirow{3}{*}{$\begin{array}{l}\text { Psychological } \\
\text { Field }\end{array}$} & Intergroup & 10,744 & 2 & 5,372 & 16,355 &, 000 \\
\hline & Withingroup & 63,394 & 193 & 328 & & \\
\hline & Total & 74,139 & 195 & & & \\
\hline \multirow[t]{3}{*}{ Social Field } & Intergroup & 9,718 & 2 & 4,859 & 11,605 &, 000 \\
\hline & Withingroup & 80,804 & 193 & 419 & & \\
\hline & Total & 90,522 & 195 & & & \\
\hline \multirow{3}{*}{$\begin{array}{l}\text { Environmental } \\
\text { Field }\end{array}$} & Intergroup & 4,890 & 2 & 2,445 & 8,430 &, 000 \\
\hline & Withingroup & 55,980 & 193 & ,290 & & \\
\hline & Total & 60,870 & 195 & & & \\
\hline \multirow{3}{*}{$\begin{array}{l}\text { Life } \\
\text { Satisfaction }\end{array}$} & Intergroup & 5,764 & 2 & 2,882 & 1,547 & ,216 \\
\hline & Withingroup & 359,590 & 193 & 1,863 & & \\
\hline & Total & 365,354 & 195 & & & \\
\hline
\end{tabular}

Pearson Correlation Analysis: Pearson Correlation analysis was conducted to investigate the relationship between the WHOQOLBREF short form of quality of life sub-dimensions and the single sub-dimension of the life satisfaction scale. The results are tabulated below.

Table 10. Pearson correlation analysis between variables.

\begin{tabular}{|c|c|c|c|c|c|}
\hline Variables & & 1 & 2 & 3 & 4 \\
\hline 1- Physical Field & $r$ & 1 & & & \\
\hline 2- Psychological Field & $r$ &, $691^{\star *}$ & 1 & & \\
\hline 3- Social Field & $r$ &, $557^{\star *}$ &, $638^{\star \star}$ & 1 & \\
\hline 4- Environmental Field & $r$ &, $583^{\star *}$ & $674^{* \star}$ &, $551^{* \star}$ & 1 \\
\hline 5- Life Satisfaction & $r$ & $429^{\star \star}$ &, $507^{\star \star}$ &, $437^{\star *}$ &, $521^{\star *}$ \\
\hline
\end{tabular}
$\mathrm{P}<.05$

Köklü, Büyüköztürk and Bökeoğlu (2006) stated that there is a $0.30<r<0.70$ medium low level relationship. Cohen (1988) stated that there is a moderate low level correlation of $0.30<r<0.50$. When the table above is examined, it is seen that there is a positive, moderately low correlation between the sub-dimensions of the World Health Organization Quality of Life-Short Form scale and the single sub-dimension of the Satisfaction with Life scale. It can be said that as the physical area, psychological area, social area and environmental area sub-dimensions of Karate Do trainers increase, their life satisfaction also increases in a positive way.

When Table 11 is examined, it is seen that the quality of life scores of Karate Do trainers, which are calculated by multiplying 
the average values of the sub-dimensions of quality of life by 4 , are high. The scale, which is a 5-point Likert type, can get the highest 20 points in each sub-dimension $(5 \times 4=20)$. When the subdimensions are examined, it is seen that the highest score is in the Psychological Field sub-dimension $(15,476)$. It is seen that the lowest score is in the Environment Area sub-dimension (14,292).

Table 11. Calculation of the averages and scores of the sub-dimensions of the quality of life scale.

\begin{tabular}{|l|l|l|l|l|l|}
\hline Sub-Dimensions & $\mathrm{n}$ & Min. & Max. & Mean & Life Quality Scores \\
\hline Physical Field & 196 & 2,00 & 5,00 & 3,867 & 15,468 \\
\hline Psychological Field & 196 & 1,00 & 5,00 & 3,869 & 15,476 \\
\hline Social Field & 196 & 1,00 & 5,00 & 3,639 & 14,556 \\
\hline $\begin{array}{l}\text { Environmental } \\
\text { Field }\end{array}$ & 196 & 1,75 & 4,88 & 3,573 & 14,292 \\
\hline
\end{tabular}

Life Satisfaction Scale consists of 7 likert type, 5 questions and one sub-dimension. "1) I have a life close to my ideals. 2) My living conditions are perfect. 3) I am satisfied with my life. 4) So far I have had the important things I want out of life. 5) If I were born again, I would not change almost anything in my life." The averages given to the questions are presented in the table below.

Table 12. Calculation of life satisfaction scores of karate do trainers.

\begin{tabular}{|l|l|l|l|}
\hline Life Satisfaction Scale & $\mathrm{n}$ & $\begin{array}{l}\text { A. } \\
\text { Mean }\end{array}$ & Sd. \\
\hline 1. In most ways my life is close to my ideal. & 196 & 4,96 & 1,636 \\
\hline 2. The conditions of my life are excellent. & 196 & 4,71 & 1,592 \\
\hline 3. I am satisfied with my life. & 196 & 5,37 & 1,492 \\
\hline $\begin{array}{l}\text { 4. So far I have gotten the important things I want in } \\
\text { life. }\end{array}$ & 196 & 5,22 & 1,555 \\
\hline $\begin{array}{l}\text { 5. If I could live my life over, I would change almost } \\
\text { anything. }\end{array}$ & 196 & 4,31 & 1,878 \\
\hline
\end{tabular}

Each item is scored between 1 and 7 , and the total score can vary between 1-35. A high score from the scale indicates that the person has high life satisfaction. The sum of the arithmetic average values in the table was calculated as 24.57 points and it was seen that the life satisfaction of the karate do trainers participating in the research was above the average point value.

\section{DISCUSSION}

When the keywords "Karate trainers, quality of life, life satisfaction" were written in the database of the National Thesis Center between January 8 and February 3,2021, the dates of the research, it was seen that no thesis was written on the subject. When the articles made in Turkey are examined in terms of keywords, it is seen that there is no article written on this subject. It is thought that the research is important in terms of the quality of life of Karate Do trainers.

Aydın's (2019) study on fitness trainers used a 5-point Likerttype life satisfaction scale developed by Diener and his friends (1985) and validated in Turkish (Köker, 1991). It has been determined that there are significant differences between life satisfaction in terms of age, education level and income level.

In Tekgöz's (2011) study examining the life satisfaction levels of football referees, The Satisfaction With Life Scale developed by Diener and his friends (1985) was used, and no significant difference was found on life satisfaction in terms of gender and education level. In the study, a positive and significant relationship was found between the duration of refereeing and life satisfaction.

The WHOQoL-BREF scale was used in the study conducted by Kotarska and his friends (2019) on participants engaged in combat sports and martial arts. The physical, psychological and environmental quality of life of the participants was at the highest level. In addition, it was stated that the participants exhibited health-oriented behaviors. It has been concluded that martial arts are an effective tool in improving the quality of life.

In the study of Dimare and his friends (2016) examining the quality of life of judo athletes, the WHOQoL-BREF scale was used and it was concluded that their quality of life was high.
The WHOQoL-BREF scale was used in the study conducted in Brazil in which the health habits and quality of life of amateur athletes in martial arts and different sports were compared. In general, it was concluded that there is a high quality of life in physical and psychological dimensions (Agnol et al., 2017).

In another study examining the quality of life of Kendo athletes in active older adults using the WHOQoL-BREF scale, it was found that the Kendo group had a statistically significantly better quality of life. High quality was determined especially in physical quality and environmental dimensions (Mendonça et al., 2017).

Arıkan, Revan, Şahin, and Altın (2020) investigated the quality of life of a total of 543 Tae Kwon Do trainers, 136 women and 409 men, working in Turkey. The WHOQoL-BREF scale was used in the study. The research was conducted in July 2019. According to the results, the quality of life of Tae Kwon Do coaches did not change according to gender and education level; It has been stated that the quality of life of the coaches with higher coaching level and income is higher.

Life Satisfaction Scale developed by Diener and his friends (1985) was used in a study in which a sample of 60 volleyball coach candidates, 27 male and 33 female, was formed and the life satisfaction of volleyball coach candidates was examined, and it was determined that female coach candidates had higher life satisfaction than male coach candidates (Baştuğ, 2009).

In a study in which 200 fitness leaders participated, the life satisfaction of fitness leaders was examined and the Life Satisfaction Scale developed by Diener and his friends (1985) was used. Findings revealed that fitness leaders' life satisfaction did not differ according to gender and professional experience (Kelecek et al., 2015).

A research was conducted on 80 referees who participated in the development seminar organized by the Turkish Weightlifting Federation in Antalya in 2011, using the Life Satisfaction Scale developed by Diener and his friends (1985). No significant difference was found between life satisfaction and gender and refereeing experience (Bahadır \& Certel, 2013).

\section{CONCLUSION}

As a result, according to the findings obtained in our research on karate do trainers, no significant difference was found between the gender of the participants and the physical, psychological, social and environmental sub-dimensions of the quality of life short form scale and the life satisfaction sub-dimension. As a result of the analyzes made, no significant difference was found between age, educational status, residence and coaching time, and the physical, psychological, social and environmental sub-dimensions of the quality of life short form scale and life satisfaction sub-dimension. A significant difference was found between the monthly income of the participants and the psychological domain, environmental domain and life satisfaction sub-dimensions of quality of life. In our research, a significant difference was found between the behaviors of the participants in accordance with the mask-distance-hygiene rules in accordance with the pandemic period conditions and all sub-dimensions of the quality of life short form scale. When the quality of life and life satisfaction of the coaches participating in the research were examined, it was seen that they scored above the average score level.

As karate do trainers pay attention to hygiene rules in every period, significant differences were observed in all sub-dimensions of quality of life and in the level of attention to mask-distancehygiene rules during the pandemic period. From this point of view, it can be said that Karate Do trainers pay attention to hygiene rules, especially during the pandemic period.

In our study, it was observed that as the quality of life of Karate Do trainers increased, their life satisfaction also increased moderately positively.

With the new regulations to be made on the living standards and personal rights of Karate Do trainers, it is predicted that their quality of life and life satisfaction will increase even more. 
Based on our results, further research from a predictive validity perspective is recommended to confirm the findings and improve their generalizability. It is recommended to conduct more research on the quality of life and life satisfaction of Karate Do trainers, to raise awareness about the quality of life and life satisfaction of trainers, and to investigate the effects of Karate Do Martial Arts on quality of life and life satisfaction.

\section{REFERENCES}

1. Alpay, H. (2016). Sensei Handbook.Turkish Karate Federation Training Books Series-07. Istanbul: Sport World Publishing.

2. Arikan, S., Revan, S., Sahin, M., \& Altin, M. (2020). Investigation of the Changes in Life Quality of Taekwondo Coaches. International Journal of Applied Exercise Physiology, 9(1), 139-148.

3. Bahadir, Z., \& Certel, Z. (2013). Evaluation of life satisfaction, selfesteem in decision-making and decision-making styles of weightlifting referees. Science, Movement and Health, 13(2), 582-587.

4. Baştuğ, G. (2009). Investigation of the relationship between empathic skills and life satisfaction of volleyball coach candidates.Journal of Physical Education and Sport Sciences,3(3), 222-227.

5. Beğli, S. (2016). Examining the quality of life of mothers of children with mild and moderate intellectual disability, comparing with the control group and determining the factors affecting the quality of life, M.Sc., Ankara University, Institute of Health Sciences, Ankara.

6. Bekmezci, M., \& Mert, I. S. (2018). Turkish validity and reliability study of life satisfaction scale. Toros University IISBF Journal of Social Sciences,5(8), 166-177.

7. Bozkurt, N. (2003). Philosophy of quality living.Journal of Istanbul Chamber of Commerce,15-16.

8. Child, D. (2006). The essentials of factor analysis. Third edition London: Continuum.

9. Cohen, J. (1988). Statistical Power Analysis For The Behavioral Sciences. New York: Academic.

10. Dimare, M., Del Vecchio, F. B., \& Xavier, B. E. B. (2016). Handgrip strength, physical activity level and quality of life of Judo master competitors. Rev Bras Educ Fis Esporte, 30(4), 847-855.

11. Field, A. (2005). Discovering statistics using spss. 2nd ed. London: Sage.

12. George, D. \& Mallery, M. (2010). SPSS for Windows Step by Step: A Simple Guide and Reference, 17.0 update (10a ed.). Boston: Pearson.

13. Gönülateş, S. (2016). The Effect of Recreational Participation on Quality of Life in Different Countries, Doctoral Thesis, Gazi University, Institute of Health Sciences, Ankara.

14. Inal, H. C. \& Günay, S. (1993). Probability and mathematical statistics. Hacettepe University Press, Ankara. Page 261; Subject of Central Limit Theorem and Law of Large Numbers.

15. Johnson, R. A. \& Wichern, D. W. (2002). Applied multivariate statisitical analysis. Prentice Hall USA. Page 175; Law of Large Numbers.

16. Karakucuk, S. (2016). Recreation Science, Ankara: Gazi Bookstore

17. Kartal, A., Ergin, E., \& Kanmış, H. D. (2020). Healthy Diet and
Physical Activity Recommendations to Improve Quality of Life during the COVID-19 Pandemic Outbreak. Eurasian Journal of Health Sciences, 3, 154

18. Kelecek, S., Altıntaş, A., Kara, F., \& Aşçı, F. H. (2015). The role of passion in determining the job and life satisfaction of fitness leaders: The case of Ankara province. Journal of Sport Sciences, 26(1), 9-17.

19. Kline R.B. (2005).Principles and Practice of Structural Equation Modeling. 2nd ed. New York: Guilford Press.

20. Kotarska, K., Nowak, L., Szark-Eckardt, M., \& Nowak, M. (2019). Selected healthy behaviors and quality of life in people who practice combat sports and martial arts. International journal of environmental research and public health, 16(5), 875.

21. Köklü, N., Büyüköztürk, Ş. \& Bökeoğlu, Ö.Ç. (2006). Statistics for the Social Sciences. Ankara: Pegem-A Publishing.

22. Mendonça, D. L. C. D., Alonso, A. C., Greve, J. M. D. A., \& Garcez Leme, L. E. (1980). Assessment of the quality of life, muscle strength, and dynamic balance of elderly Kendo players.Clinics [online]. 2017, vol. 72, n. 11. ISSN, 5322, 661-666.

23. Özata, M. (2019). The effect of smartphone addiction symptoms on sleep quality and quality of life, Master Thesis, Beykent University, Institute of Social Sciences, Istanbul.

24. Özer, M., \& Karabulut, Ö. Ö. (2003). Satisfaction of life in elderly individuals. Turk J Geriatrics, 6, 72-4.

25. Perim, A. (2007). Determination of Quality Life Perception of Nurses Working in Trakya University Education, Research and Practice Hospital, Master's thesis, Trakya University Faculty of Medicine, Institute of Health Sciences, Edirne.

26. Savcı, B. A. (2006). Factors Affecting Quality of Life and Social Support Level in Cancer Patients, Master Thesis, Atatürk University, Institute of Health Sciences, Erzurum.

27. Sevil, T. (2015). The effect of participation in therapeutic recreational activities on perceived leisure satisfaction, life satisfaction and quality of life of the elderly, PhD Thesis, Anadolu University, Institute of Health Sciences, Eskişehir.

28. Tabachnick, B.G.\& Fidell, L.S. (2001). Using multivariate statistics. Fourth edition. Boston: Allyn and Bacon.

29. Tekgöz, U. (2011). Examining the relationships between the job stress, job satisfaction and life satisfaction levels of football referees: A research on 3rd district referees, Master Thesis, Erciyes University, Institute of Health Sciences, Kayseri.

30. Telatar, T. G. (2007). Determination of the quality of life and risky behaviors of men aged 20-24 working in industry, Specialization Thesis, Hacettepe University Faculty of Medicine, Department of Public Health, Ankara.

31. Tunç, A. Ç., Zorba, E., \& Çingöz, Y. E. (2020). The Effect of Exercise on Quality of Life during the Covid 19 Epidemic. International Journal of Contemporary Educational Research, 6(1), 127-135.

32. Turkish Language Association (TDK). (2021). Current Turkish Dictionary, https://sozluk.gov.tr/, Accessed on 27.01. 2021.

33. Üstün, M. E. (2006). Karadeniz G. The quality of life of patients undergoing hemodialysis treatment and the importance of informative nursing approach. Firat Journal of Health Services, 1(1), 33-34. 